\title{
PENERAPAN STRATEGI PROBLEM POSING PADA MATERI HIMPUNAN DI SMP NEGERI 8 KOTA PROBOLINGGO
}

\author{
Sudarmanto \\ SMPN 8 Jalan Salak No. 137 Kota Probolinggo Jawa Timur Telp. (0335) 420168 \\ E_mail: sudarmanto_165@yahoo.co.id
}

\begin{abstract}
ABSTRAK
Tujuan penelitian ini adalah untuk mendiskripsikan pelaksanaan Strategi Pembelajaran Problem Posing dan hasil belajar siswa terhadap materi himpunan di SMP Negeri 8 Kota Probolinggo kelas VII.7. Problem Posing Learning adalah strategi pembelajaran yang mengharuskan siswa untuk merumuskan ulang soal yang telah ada atau memecah suatu soal menjadi pertanyaan-pertanyaan yang lebih sederhana secara mandiri untuk dicarikan penyelesaiannya (jawabnya) baik secara individu maupun kelompok ataupun bersama guru, terutama pada soal-soal yang dianggap rumit. Metode yang digunakan dalam penelitian ini adalah penelitian tindakan kelas (Classroom Action Research). Secara umum hasil penelitian menunjukkan Strategi Pembelajaran Problem Posing dapat terlaksana dengan baik dan siswa dapat mengikutinya dengan baik dan merasa senang. Hasil evaluasi belajar siswa menunjukkan adanya peningkatan. Rerata kelas nilai siswa dari siklus I ke siklus II ada peningkatan sebesar 4,3 dari siklus II ke siklus III ada peningkatan sebesar 9,1. Siswa yang belajarnya tuntas pada siklus I sebanyak 15 orang atau sekitar 55,6\% pada siklus II sebanyak 21 orang atau sekitar 77,8\%, dan pada siklus III sebanyak 25 orang atau sekitar 92,6\%.
\end{abstract}

Kata Kunci: Problem Posing Learning dan Hasil Belajar

\begin{abstract}
The purpose of this study is to describe the implementation of the Learning Strategies of Problem Posing and the students learning result toward the material of compound at SMP Negeri 8 Probolinggo. Problem Posing Learning is a learning strategy that requires students to reformulate the existing problems or break the problem into the simpler questions independently to look for the solution (answer) either individually or in groups or with a teacher, especially for the questions which are considered complicated. The method used in this research is the classroom action research. In general, the results showed Learning Strategy Problem Posing can be done well and the students can do it well and feel happy. The evaluation results showed the increasing of students learning result. There is an increasing mean of the students's score grade from the first cycle to the second cycle for about 4.3 of a second cycle to the third cycle for about 9.1. The students who complete the first cycle study of 15 people, or approximately $55.6 \%$, in the second cycle as many as 21 people, or for about $77.8 \%$, and in the third cycle of 25 people, or approximately $92.6 \%$.
\end{abstract}

Keywords: Problem Posing Learning and Learning Result

\section{Pendahuluan}

Salah satu permasalahan dalam proses pembelajaran matematika di kelas seringkali diketahui setelah dilakukan evaluasi, dimana hasilnya tidak memuaskan atau tidak maksimum. Hal ini terjadi salah satunya dikarenakan siswa kurang terlibat dalam proses 
pembelajaran sehingga ada kecenderungan pada siswa pasif atau hanya menerima informasi pengetahuan dari guru tanpa reserve. Kelemahan gaya belajar siswa yang pasif ini akan menghasilkan daya serap atau hasil belajar rendah dan tidak tuntas atau tidak maksimum.

Banyak faktor yang menyebabkan siswa kurang ada keterlibatan dalam proses pembelajaran matematika. Menurut pengakuan beberapa siswa, salah satu di antaranya adalah siswa merasa jenuh atau bosan dengan metode yang di awali dengan penjelasan materi kemudian diberi contoh soal lalu dilanjutkan dengan latihan-latihan soal pada buku paket atau lembar kerja siswa (LKS).

Dari permasalahan tersebut penulis mencoba melakukan penelitian penerapan Strategi Pembelajaran Problem Posing atau Problem Posing Learning (PPL) terhadap materi himpunan di SMP Negeri 8 Kota Probolinggo, dengan harapan siswa dapat lebih aktif terlibat dalam proses pembelajaran sehingga ada peningkatan hasil belajar karena dalam Strategi Pembelajaran Problem Posing siswa diupayakan ada keterlibatan dalam proses pembelajaran dengan cara merumuskan ulang soal yang telah ada secara mandiri dengan beberapa perubahan agar lebih sederhana dan dapat dikuasai untuk dicarikan penyelesaiannya baik secara individu maupun kelompok ataupun bersama guru setelah diberikan perlakuan khusus (treatment).

Tujuan penelitian ini adalah; 1)Untuk mendiskripsikan pelaksanaan Strategi Pembelajaran Problem Posing terhadap materi himpunan di SMP Negeri 8 Kota Probolinggo, 2)Untuk mengungkapkan hasil belajar siswa setelah diberi perlakuan dengan Strategi Pembelajaran Problem Posing.

Pertanyaannya, adalah; Bagaimanakah hasil belajar siswa kelas VII.7 di SMP Negeri 8 Kota Probolinggo setelah diberi perlakuan dengan Strategi Pembelajaran Problem Posing?

\section{Materi Himpunan di SMP}

Dalam Kurikulum tahun 2006 atau Kurikulum Tingkat Satuan Pendidikan (KTSP), materi himpunan di SMP diberikan pada kelas VII dengan Standar Kompetensi; 4.Menggunakan konsep himpunan dan diagram venn dalam pemecahan masalah Rincian Kompetensi Dasar (KD) ditunjukkan pada tabel sebagai berikut: 
Tabel 1. Rincian Kompetensi Dasar (KD)

\begin{tabular}{|c|c|c|}
\hline Kompetensi Dasar & $\begin{array}{l}\text { Alokasi Waktu } \\
\text { Dalam Jampel }^{*}\end{array}$ & Indikator Keberhasilan \\
\hline $\begin{array}{l}\text { 4.1 Memahami pengertian dan } \\
\text { notasi himpunan serta } \\
\text { penyajiannya }\end{array}$ & 2 jampel & $\begin{array}{l}\text { - Menyatakan masalah sehari-hari dalam } \\
\text { bentuk himpunan dan mendata } \\
\text { anggotanya } \\
\text { - Menyebutkan anggota dan bukan } \\
\text { anggota himpunan } \\
\text { - Menyatakan notasi himpunan } \\
\text { - Mengenal himpunan kosong dan } \\
\text { notasinya }\end{array}$ \\
\hline $\begin{array}{l}\text { 4.2 Memahami konsep } \\
\text { himpunan bagian }\end{array}$ & 4 jampel & $\begin{array}{l}\text { - Menentukan himpunan bagian dari } \\
\text { suatu himpunan } \\
\text { - Mengenal pengertian himpunan } \\
\text { semesta, serta dapat menyebutkan } \\
\text { anggotanya }\end{array}$ \\
\hline $\begin{array}{l}\text { 4.3 Melakukan operasi irisan, } \\
\text { gabungan, kurang } \\
\text { (difference) dan } \\
\text { komplemen pada } \\
\text { himpunan }\end{array}$ & 6 jampel & $\begin{array}{l}\text { - Menjelaskan pengertian irisan dan } \\
\text { gabungan dua himpunan } \\
\text { - Menjelaskan kurang(difference) suatu } \\
\text { himpinan dari himpunan lainnya } \\
\text { - Menjelaskan komplemen dari suatu } \\
\text { himpunan }\end{array}$ \\
\hline $\begin{array}{l}\text { 4.4 Menyajikan himpunan } \\
\text { dengan diagram venn }\end{array}$ & 2 jampel & $\begin{array}{l}\text { - Menyajikan gabungan atau irisan dua } \\
\text { himpunan dengan diagram Venn } \\
\text { - Menyajikan kurang(difference) suatu } \\
\text { himpunan dari himpunan lainnya } \\
\text { dengan diagram Venn } \\
\text { - Menyajikan komplemen suatu } \\
\text { himpunan dengan diagram Venn }\end{array}$ \\
\hline $\begin{array}{l}\text { 4.5 Menggunakan konsep } \\
\text { himpunan dalam } \\
\text { pemeahan masalah }\end{array}$ & 2 jampel & $\begin{array}{l}\text { - Menyelesaikan masalah dengan } \\
\text { menggunakan diagram Venn dan } \\
\text { konsep himpunan }\end{array}$ \\
\hline Jumlah & 16 jampel & \\
\hline
\end{tabular}

Keterangan: Jampel $^{*)}=$ Jam Pelajaran

\section{Problem Posing Learning (PPL)}

Menurut Brown dan Walter

(1993) model pembelajaran Problem

Posing ini pertama kali digunakan secara resmi oleh National Council of Teachers of Mathematics pada tahun 1989 kemudian mulai dikembangkan oleh Lyn D. English tahun 1997 pada mata pelajaran matematika dan selanjutnya, model ini dikembangkan pula pada mata pelajaran yang lain (Herdian, 2009).

Problem Posing dapat berarti pembentukan soal (Suryanto, 1998 dan As'ari, 2000), membuat soal (Sutiarso, 1999:16), pengajuan soal (Siswono,1999), dan pengkonstruksian masalah (Suharta,2000). Dalam pustaka 
pendidikan matematika, Problem Posing memiliki beberapa pengertian. Pertama, Problem Posing adalah perumusan soal sederhana atau perumusan ulang soal yang telah ada dengan beberapa perubahan agar lebih sederhana dan dapat dipahami dalam rangka memecahkan soal yang rumit. Kedua, Problem Posing adalah perumusan soal yang berkaitan dengan syarat-syarat pada soal yang telah diselesaikan dalam rangka mencari alternatif pemecahan lain . Ketiga, Problem Posing adalah perumusan soal dari informasi atau situasi yang telah tersedia, baik dilakukan sebelum, ketika, atau setelah penyelesaian suatu soal. Dengan demikian pembelajaran Problem Posing dapat diartikan sebagai strategi pembelajaran yang mengharuskan siswa untuk merumuskan ulang soal yang telah ada atau memecahkan suatu soal menjadi pertanyaan-pertanyaan yang lebih sederhana secara mandiri dengan bebrapa perubahan agar lebih sederhana dan dapat dikuasai untuk dicarikan penyelesaiannya (jawabnya) baik secara individu maupun kelompok ataupun bersama guru terutama pada soal-soal yang dianggap rumit (Abdussakir, 2009)

Dalam teori belajar, bahwa seorang siswa dikatakan telah belajar apabila telah ada perubahan tingkah laku sebagai hasil dari pengalamannya atau sebagai hasil interaksi dengan lingkungannya dalam memenuhi kebutuhannya, sedangkan yang dimaksud dengan mengajar adalah menata lingkungan agar siswa termotivasi dalam menggali makna serta menghargai ketidakmenentuan (Degeng, 2007; 3). Belajar bukan sekedar mengumpulkan pengetahuan, fakta, dalil-dalil, rumusrumus, algoritma, dan yang sejenisnya. Tetapi belajar merupakan suatu proses mental yang terjadi dalam diri seseorang. Belajar ialah suatu proses usaha yang dilakukan seseorang untuk memperoleh suatu perubahan tingkah laku yang baru secara keseluruhan, sebagai hasil pengalamannya sendiri dalam interaksi dengan lingkungannya (Slameto, 2003:2). Proses belajar itu pada hakekatnya adalah kegiatan mental sehingga, bukti yang dapat disaksikan bahwa seseorang telah belajar adalah adanya gejala -gejala perubahan prilaku (Hamalik, 2003:29).

Dalam Strategi Pembelajaran Problem Posing terfokus pada upaya peserta didik secara sengaja menemukan pengetahuan dan pengalamanpengalaman baru melalui perumusan soal, dengan harapan peserta didik dapat termotivasi untuk dapat berpikir kritis, dialogis, kreatif dan interaktif karena peserta didik dilibatkan untuk mengambil peran dalam proses pembelajaran atau terlibat secara langsung dan punya pengalaman dalam kegiatan 
pembelajaran, yaitu dalam bentuk tuntutan mengajukan masalah atau pertanyan (Problem Posing) beserta jawabnya. Silver dan Cai, 1996 (dalam Abdussakir, 2009) menyarankan agar pembelajaran matematika lebih ditekankan pada kegiatan problem posing karena untuk meningkatkan kemampuan siswa dalam menyelesaikan soal dapat dilakukan dengan cara membiasakan siswa mengajukan soal.

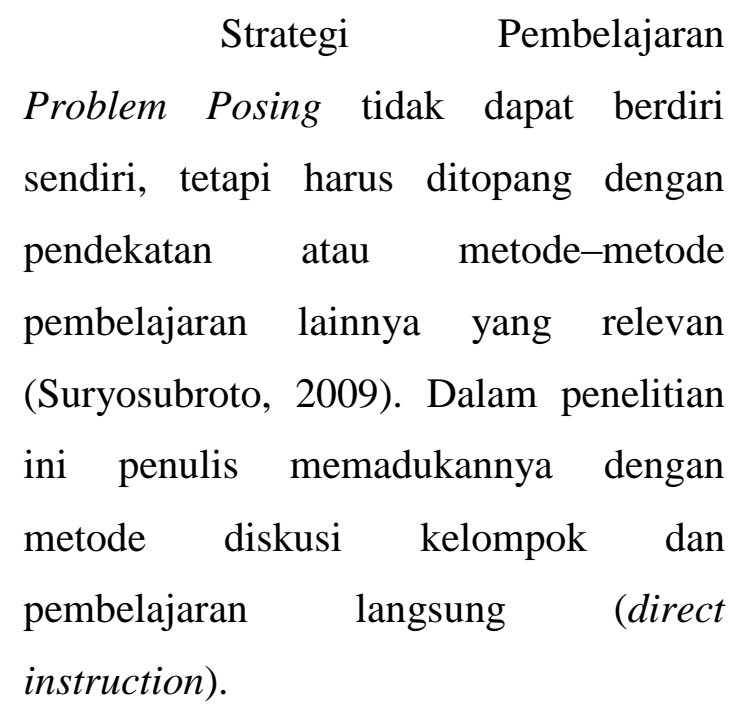

Sintaks Model Pembelajaran Problem Posing

Dari beberapa literatur didapati beragam sintaks pelaksanaan Strategi Pembelajaran Problem Posing, tetapi kegiatan utama yaitu tuntutan pengajuan masalah atau perumusan soal (Problem Posing) terhadap peserta didik tetap harus ada, karena kegiatan inti dari Strategi Pembelajaran Problem Posing adalah pengajuan masalah atau pengajuan pertanyaan berupa rumusan soal-soal.
Dengan demikian sintaks pembelajaran model Problem Posing meliputi; 1)Pembukaan, 2)Guru menyampaikan materi sebagai pengantar, 3)Peserta didik diminta untuk menyusun/membuat soal dan penyelesaiannya, 4)Soal yang disusun didiskusikan dengan teman, 4)Guru membahas dan memberi penguatan terhadap soal dan jawaban yang dibuat siswa.

\section{Metode Penelitian}

Penelitian ini dilaksanakan di SMP Negeri 8 Kota Probolinggo Kelas VII.7 pada tahun pelajaran 2013/2014 semester genap dengan subjek penelitian sebanyak 27 siswa. Metode yang digunakan adalah Penelitian Tindakan Kelas (PTK) model Kemmis dan Taggart yang berbentuk spiral dari siklus I ke siklus berikutnya. Dalam penelitian ini terdiri dari tiga siklus tujuh kali pertemuan atau tatap muka.

\section{Prosedur Penelitian}

Prosedur penelitian pada siklus I; tahap perencanaan meliputi; 1)Penyusunan rancangan kegiatan pembelajaran. 2)Mengorganisasikan bahan pembelajaran. 3)Menyusun rencana pelaksanaan pembelajaran (RPP) dan instrumen penilaian serta indikator keberhasilan pelaksanaan pembelajarannya. Sedangkan tahap tindakannya adalah; 1)Guru 
menyampaikan topik dan tujuan pembelajaran. 2)Guru menyampaikan kegiatan pembelajaran yang akan diterapkan, yaitu Strategi Pembelajaran Problem Posing. 3)Guru menjelaskan materi himpunan. 4)Guru membagi peserta didik dalam kelompok yang terdiri dari 4-5 orang. 5)Guru meminta kepada masing-masing kelompok untuk membaca dan memahami isi materi yang disajikan. 6)Tiap kelompok menyusun pertanyaan dan jawabnya berdasarkan materi yang dibaca. 7)Pertanyaan dan jawaban ditulis pada Lembar Kerja Problem Posing (LKPP) I. 8)Masingmasing kelompok mempresentasikan hasil kerjanya, dan meminta kelompok lain untuk memberikan tanggapannya. 9)Guru memberikan penguatan dan membimbing peserta didik untuk menyusun kesimpulan.

Tahap observasi, kegiatannya dilakukan bersamaan dan setelah pelaksanaan serangkaian tindakan pembelajaran dengan fokus pengamatan pada aktivitas atau pengalaman siswa serta produk yang dihasilkan sebagai indikator kemampuan siswa dalam merumuskan soal.

Prosedur penelitian pada siklus II; tahap perencanaannya meliputi; 1)Menganalisis hasil observasi siklus I. 2)Mengorganisasikan bahan pembelajaran. 3)Menyusun rencana pelaksanaan pembelajaran (RPP) serta indikator keberhasilannya. Tahap tindakannya adalah; 1)Guru mengorganisasikan siswa ke dalam kelompoknya. 2)Guru menyampaikan hasil kegiatan pembelajaran yang berkenaan dengan Strategi Pembelajaran Problem Posing pada siklus I. 3)Guru meminta kepada masing-masing kelompok untuk membaca dan memahami isi materi, contoh soal dan jawaban yang disajikan. 4)Tiap kelompok memecah atau menyusun pertanyaan dan jawabnya berdasarkan contoh soal yang disajikan. 5)Pertanyaan dan jawaban ditulis pada Lembar Kerja Problem Posing (LKPP) II. 6)Masing-masing kelompok mempresentasikan hasil kerjanya, dan meminta kelompok lain untuk memberikan tanggapannya. 7)Guru memberikan penguatan dan membimbing peserta diudik untuk menyusun kesimpulan.

Kegiatan observasi pada siklus II ini masih sama dengan pada siklus I, yaitu fokus pada aktivitas atau pengalaman siswa serta produk yang dihasilkan.

Prosedur penelitian pada siklus III; tahap perencanaannya meliputi; 1)Menganalisis hasil observasi siklus II. 2)Mengorganisasikan bahan pembelajaran. 3)Menyusun rencana pelaksanaan pembelajaran (RPP) serta 
indikator keberhasilannya. Tahap tindakannya adalah; 1)Guru mengorganisasikan siswa ke dalam kelompoknya. 2)Guru menyampaikan hasil kegiatan pembelajaran yang berkenaan dengan Strategi Pembelajaran Problem Posing pada siklus II. 3)Guru meminta kepada masing-masing kelompok untuk membaca dan memahami isi materi, soal dan jawaban yang disajikan. 4)Tiap kelompok memecah atau menyusun pertanyaan dan jawabnya berdasarkan soal yang disajikan. 5)Pertanyaan dan jawaban ditulis pada Lembar Kerja Problem Posing (LKPP) III. 6)Masing-masing kelompok mempresentasikan hasil kerjanya, dan meminta kelompok lain untuk memberikan tanggapannya. 7)Guru memberikan penguatan dan membimbing peserta diudik untuk menyusun kesimpulan. 8)Siswa secara individu diberi soal-soal evaluasi.

Kegiatan observasi pada siklus III ini masih sama dengan pada siklus II, yaitu fokus pada aktivitas atau pengalaman siswa serta produk yang dihasilkan.

\section{Hasil dan Pembahasan}

\section{Data Kegiatan Guru}

Data kegiatan guru selama proses pelaksanaan Strategi Pembelajaran Problem Posing dari siklus I sampai dengan siklus III dapat penulis tunjukkan pada tabel sebagai berikut:

Tabel 2. Data Hasil Observasi Kegiatan Guru Siklus I s.d III

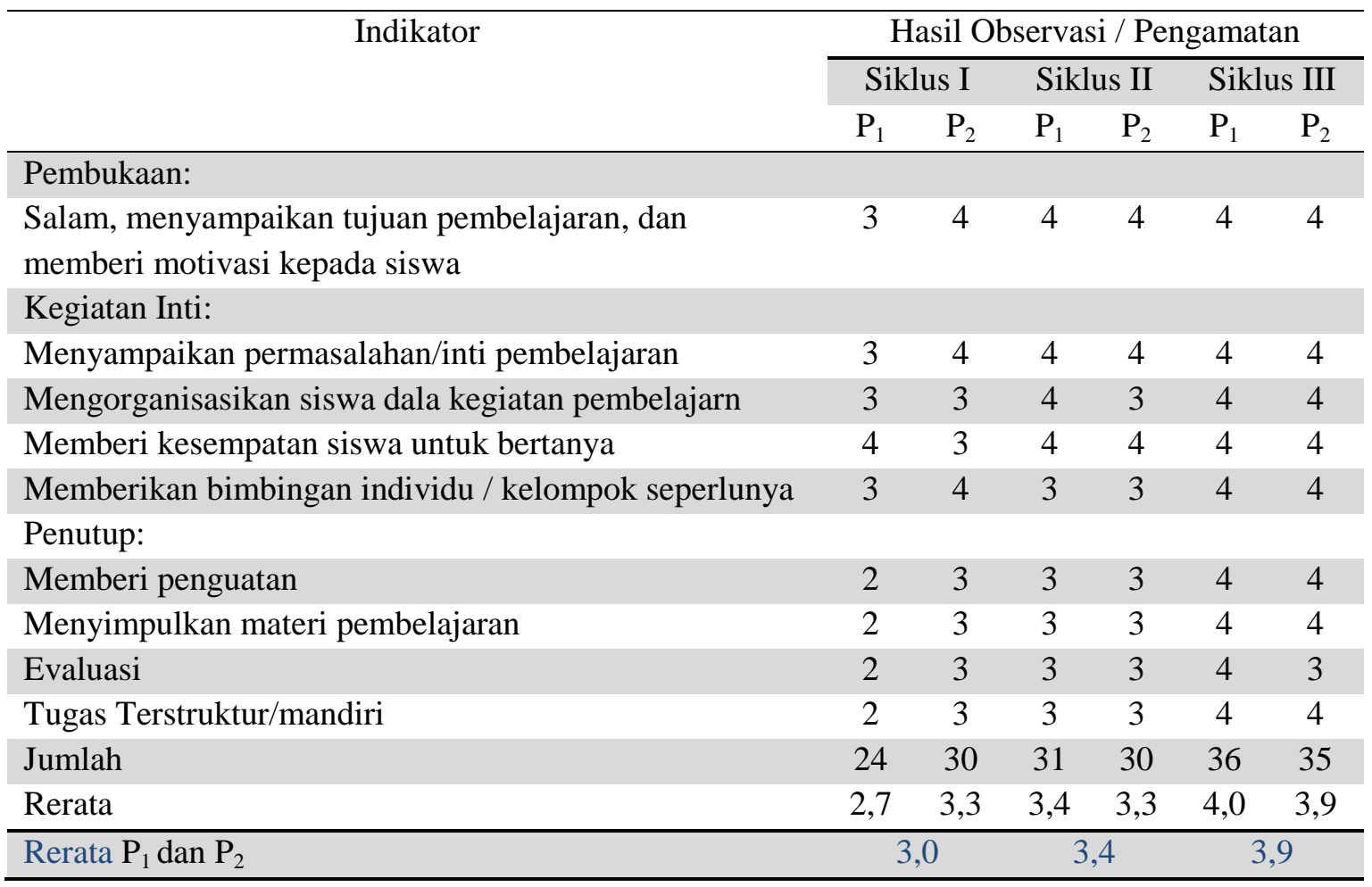


Keterangan:

$\mathrm{P}_{1} \quad=$ Pengamat 1

$4=$ Baik sekali

$2=$ Cukup

$\mathrm{P}_{2} \quad=$ Pengamat 2

$3=$ Baik

$1=$ Kurang

$\bar{X}=$ Rerata perolehan observasi pengamat 1 dan pengamat 2

Dari hasil observasi pada tabel 1 dapat penulis jelaskan, bahwa kegiatan guru dalam melaksanakan Strategi Pembelajaran Problem Posing pada materi himpunan dari siklus I sampai dengan siklus III terkontrol sesuai dengan skenario pembelajaran yang telah tertuang dalam rencana program pembelajaran (RPP). Skor yang berikan oleh observer berada dalam rentangan baik sampai dengan baik sekali, yaitu pada pada siklus I memperoleh skor rerata sebesar 3,0; siklus II memperoleh skor 3,4; dan pada siklus III mencapai skor 3,9 .

\section{Data Aktivitas Siswa}

Data aktivitas siswa selama kegiatan pembelajaran dari siklus I s.d siklus III dapat penulis tunjukkan pada tabel sebagai berikut:

Tabel 3. Data Aktivitas Siswa Siklus I s.d III

\begin{tabular}{lccccccc}
\hline \multirow{2}{*}{ Indikator } & \multicolumn{5}{c}{ Hasil Observasi / Pengamatan } \\
\cline { 2 - 8 } & \multicolumn{2}{c}{ Siklus } & \multicolumn{2}{c}{ Siklus II } & \multicolumn{3}{c}{ Siklus III } \\
& $\mathrm{P}_{1}$ & $\mathrm{P}_{2}$ & $\mathrm{P}_{1}$ & $\mathrm{P}_{2}$ & $\mathrm{P}_{1}$ & $\mathrm{P}_{2}$ \\
\hline Memperhatikan penjelasan guru & 3 & 3 & 3 & 3 & 3 & 4 \\
Keseriusan dalam diskusi kelompok & 2 & 2 & 4 & 3 & 4 & 4 \\
Animo siswa untuk bertanya kepada teman dalam & 2 & 2 & 2 & 3 & 3 & 3 \\
kelompok / guru & & & & & & \\
Presentasi kelompok & 2 & 2 & 3 & 3 & 4 & 4 \\
Produk siswa & 2 & 2 & 2 & 3 & 4 & 4 \\
Jumlah & 11 & 11 & 14 & 15 & 18 & 19 \\
Rerata & 2,2 & 2,2 & 2,8 & 3,0 & 3,6 & 3,8 \\
\hline Rerata $\mathrm{P}_{1}$ dan $\mathrm{P}_{2}$ & \multicolumn{2}{c}{2,2} & \multicolumn{2}{c}{2,9} & \multicolumn{3}{c}{3,7} \\
\hline
\end{tabular}

Keterangan:

$\begin{array}{rlrr}\mathrm{P}_{1} & =\text { Pengamat } 1 & 4 \text { = Baik sekali } & 2=\text { Cukup } \\ \mathrm{P}_{2} & =\text { Pengamat } 2 & 3=\text { Baik } & 1=\text { Kurang } \\ \bar{X} & =\text { Rerata perolehan observasi pengamat } 1 \text { dan pengamat } 2\end{array}$

$\bar{X}=$ Rerata perolehan observasi pengamat 1 dan pengamat 2

Dari tabel data kegiatan siswa (tabel 2) selama mengikuti kegiatan pembelajaran menunjukkan adanya peningkatan aktivitas siswa yang baik, yaitu observer mengamati dari siklus I sampai siklus III, mencatat skor cukup sampai dengan amat baik. Dalam penilaian aktivitas siswa di sini digunakan skala predikat; kurang, cukup atau sedang, baik, dan baik sekali atau 
amat baik. Cara menentukan predikat tersebut adalah dengan cara mencocokkan dan menghitung kemunculan prilaku siswa yang sesuai dengan instrumen pengamatan. Jumlah kemunculan prilaku siswa kemudian dikategorikan; jika $0 \%<\mathrm{x} \leq 25 \%=1$ (kurang), $25 \%<x \leq 50 \%=2$ (cukup atau sedang), $50 \%<x \leq 75 \%=3$ (baik), dan $75 \%<\mathrm{x} \leq 100 \%=4$ (baik sekali atau amat baik).

Dari catatan teman sejawat, perhatian siswa terhadap penjelasan guru hampir tidak ditemukan permasalahan yang memerlukan penanganan dengan serius karena secara umum rerata siswa selalu memperhatikan penjelasan guru, yaitu mendapat skor 3 .

Prilaku siswa dalam diskusi kelompok pada siklus I masih banyak siswa yang main-main atau bergurau dalam kelompoknya, sehingga diskusi kelompok tidak serius. Hal ini penulis maklumi karena anak seusia siswa SMP kelas VII masih ada kecenderungan suka bermain. Upaya yang penulis lakukan, adalah dengan penuh kasih sayang dan kesabaran mengajak siswa untuk lebih serius lagi berdiskusi pada pertemuan berikutnya. Memberi janji kepada siswa yang serius berdiskusi akan diberikan nilai tambahan. Ternyata siswa dapat lebih serius berdiskusi dalam kelompoknya pada pertemuan berikutnya, sehingga bisa mencapai skor 4. Animo siswa untuk bertanya pada siklus I dan II cukup, sedangkan pada siklus III adalah baik. Namun siswa cenderung lebih suka bertanya kepada guru dibanding kepada temannya jida ada kesulitan yang dihadapi. Dalam presentasi kelompok, cukup baik siswa ada motivasi untuk memperesentasikan hasil kerja kelompoknya.

Produk siswa dari siklus I sampai dengan siklus III menunjukkan adanya peningkatan yang signifikan, dalam arti siswa ada peningkatan dalam merumuskan ulang soal-soal yang berkenaan dengan himpunan. Produk siswa berupa rumusan soal beserta jawabannya ini merupakan inti dari Strategi Pembelajaran Problem Posing. Pada siklus I mencapai 50\% siswa dapat merumuskan soal beserta jawabannya yang oleh observer diberi skor 2. Pada siklus III bisa dikatakan $100 \%$ siswa dapat merumuskan soal-soal beserta jawabannya dengan baik.

\section{Data Hasil Evaluasi Belajar Siswa}

Data hasil evaluasi belajar siswa dari siklus I s.d siklus III dapat penulis tunjukkan pada tabel sebagai berikut: 
Tabel 4. Data Hasil Evaluasi Siswa Siklus I s.d III

\begin{tabular}{lcccccc}
\hline \multicolumn{1}{c}{ Siklus } & Nilai & Nilai & Jumlah & Nilai & \multicolumn{2}{c}{ Siswa Yang Tuntas } \\
\cline { 7 - 8 } & Terendah & Tertinggi & Nilai & Rerata Kelas & Jumlah & Persentase \\
Siklus I & 60 & 90 & 2010 & 74,4 & 15 & $55,6 \%$ \\
Siklus II & 65 & 90 & 2025 & 78,7 & 21 & $77,8 \%$ \\
\hline Siklus III & 60 & 100 & 2370 & 87,8 & 25 & $92,6 \%$ \\
\hline
\end{tabular}

Dari hasil pendataan pada tabel 3 di atas dapat dijelaskan bahwa hasil evaluasi hasil belajar siswa, jika dilihat dari perolehan nilai siswa yang terendah tidak ada perubahan yang signifikan, bahkan dari siklus I ke siklus II naik 5 angka kemudian pada siklus III turun lagi 5 angka. Sedangkan pada perolehan nilai tertinggi siswa dari siklus II ke siklus III mengalami kenaikan 10 angka, yaitu dari 90 menjadi 100.

Rerata perolehan nilai kelas, pada siklus I rerata nilai siswa mencapai 74,4 . Pada siklus II rerata nilai siswa mencapai 78,7. Pada siklus III peroleh rerata nilai siswa mencapai 87,8. Hal ini dapat diartikan bahwa dari siklus I ke siklus II rerata nilai siswa terjadi peningkatan sebesar 4,3 dan dari siklus II ke siklus III rerata nilai siswa terjadi peningkatan sebesar 9,1. Sehingga dapat diartikan selama pelaksanaan Strategi Pembelajaran Problem Posing pada materi himpunan dari siklus I samapai dengan siklus III rerata nilai siswa terjadi peningkatan sebesar 13,4.
Adapun siswa yang tuntas pada siklus I sebanyak 15 orang atau sekitar $55,6 \%$. Pada siklus II siswa yang tuntas sebanyak 21 orang atau sekitar 77,8\%. Pada siklus III siswa yang tuntas belajarnya sebanyak 25 orang atau sekitar $92,6 \%$.

Dari paparan tersebut dapat diartikan bahwa dari siklus I ke siklus II ketuntasan belajarnya terjadi peningkatan sebesar 22,2\% atau ada peningkatan sebanyak 6 orang siswa. Dari siklus II ke siklus III ketuntasan belajarnya terjadi peningkatan sebesar $14,8 \%$ atau ada peningkatan sebanyak 4 orang. Sehingga selama pelaksanaan Strategi Pembelajaran Problem Posing pada pada materi himpunan dari siklus I samapai dengan siklus III dapat diartikan ketuntasan belajar siswa terjadi peningkatan sebesar $37 \%$ atau ada peningkatan sebanyak 10 orang.

\section{Kelebihan dan Kekurangan Model Pembelajaran Problem Posing}

Dalam teori pembelajaran sudah maklum bahwa tidak ada satu model pembelajaranpun yang dikatakan 
paling baik dan paling cocok diterapakan pada semua siswa dalam situasi bagaimanapun. Akan tetapi satu model pembelajaran dikatakan baik apabila diterapakan pada situasi dan kondisi yang tepat dengan model pembelajaran itu sendiri dan ada dukungan dari sarana maupun prasarananya serta oleh guru dan siswa itu sendiri. Tidak terkecuali, dengan Strategi Pembelajaran Problem Posing ini juga memiliki kekurangan di samping banyak kelebihannya.

$$
\text { Adapun }
$$

kelebihan

pembelajaran Problem Posing berdasarkan pengalaman penulis yang telah penulis terapkan di SMP Negeri 8 Kota Probolinggo, antara lain; 1)Dapat membantu kemampuan siswa dalam memecahkan masalah dari kesulitan menghadapi soal tentang himpunan yang dianggap sulit oleh siswa. 2)Dapat mengembangkan perngetahuan dan pemahaman siswa terhadap materi himpunan. 3)Siswa lebih terampil menyelesaikan soal-soal tentang materi himpunan karena soal dibuat sendiri oleh siswa dan sudah dipresentasikan atau diskusi kelas. 4)Dapat meningkatkan kemampuan siswa dalam bertanya atau mengajukan permasalahan (soal). 5)Dapat meningkatkan perhatian siswa terhadap materi pelajaran yang diberikan (materi himpunan). 5)Dapat meningkatkan motivasi siswa dalam memahami dan menyelesaikan permasalahan atau soal-soal materi himpunan. 6)Bagi guru dapat mengetahui proses bagaimana cara siswa memecahkan masalah. 7)Kegiatan pembelajaran tidak lagi terpusat pada guru karena pembelajaran Problem Posing menuntut keaktifan dan kreatifitas siswa dalam merumuskan soal-soal beserta jawabannya.

Sedangkan kekurangannya adalah model pembelajaran Problem Posing membutuhkan waktu yang lama dan kesabaran dari guru, karena sering kali guru kurang sabar melihat hasil kerja siswa yang kurang maksimal. Hal ini dapat terjadi karena guru (khusunya guru matematika) sudah terbiasa dengan metode konvensional yang berpusat pada kegiatan guru (teacher centered).

\section{Kesimpulan}

Strategi Pembelajaran Problem Posing atau Problem Posing Learning (PPL) terhadap materi himpunan kelas VII di SMP Negeri 8 Kota Probolinggo dapat dilaksanakan dengan baik, yaitu sesuai dengan perencanaan pembelajaran yang telah ditetapkan. Aktivitas siswa selama mengikuti kegiatan pembelajaran juga menunjukkan minat yang baik sebagaimana yang ditunjukkan oleh tabel hasil penelitian. Hasil observasi menunjukkan kegiatan guru dari siklus I 
sampai dengan siklus III berada dalam rentangan baik sampai dengan baik sekali. Skor rerata siklus I sebesar 3,0; siklus II sebesar 3,4; dan siklus III sebesar 3,9. Hasil evaluasi hasil belajar siswa dari siklus I samapi dengan siklus III menunjukkan adanya peningkatan. Dari siklus I ke siklus II rerata nilai siswa meningkat sebesar 4,3 dan siswa yang tuntas meningkat sebesar $22,2 \%$. Dari siklus II ke siklus III rerata nilai siswa meningkat sebesar 9,1 dan siswa yang tuntas meningkat sebesar $14,8 \%$.

\section{Ucapan Terimakasih}

Dalam kesempatan ini, tak lupa penulis ucapkan terima kasih yang tak terhingga kepada teman sejawat di SMP Negeri 8 Kota Probolinggo, bapak Wiwit Surya Subandono, S.Pd.Fis. dan ibu Dra. Sri Sulistyawati yang telah sudi meluangkan waktunya untuk bertindak sebagai observer sejak dari siklius pertama sampai selesai (siklus III) sehingga pelaksanaan penelitian ini berjalan sesuai dengan rencana.

\section{Pustaka}

Abdussakir.2013.

Pembelajaran

Matematika Dengan Problem
Posing. $\quad$ https:
abdussakir.wordpress.com
/2009/02/13/ pembelajaranmatematika-dengan-problemposing/
Degeng, I Nyoman Sudana. 2007. Pembaharuan Paradigma

Pembelajaran Dari Behavioristik ke Konstruktivistik. Makalah Orasi Ilmiah disajikan dalam Wisuda Program Pascasarjana, Sarjana \& Diploma - II Universitas PGRI Adibuana Surabaya, 30 Juni 2007.

Hamalik, Oemar. 2003. Proses Belajar Mengajar. Jakarta: Bumi Aksara.

Herdian (2009). Model Pembelajaran Problem Posing. http://herdy07. wordpress.com

Siswono, Y.T.E., 2000. Pengajuan Soal (Problem Posing) dalam Pembelajaran Matematika di Sekolah (Implementasi dari Hasil Penelitian). Makalah disajikan pada Seminar Nasional Pengajaran Matematika Sekolah Menengah, 25 Maret 2000. Malang: FMIPA Universitas Negeri Malang.

Slameto. 2003. Belajar dan FaktorFaktor yang Mempengaruhinya. Jakarta; Rineka Cipta. Cet. Keempat (edisi revisi).

Suharta, I.G.P. 2000. Pengkonstruksian Masalah oleh Siswa (Suatu Strategi Pembelajaran Matematika). Makalah disajikan pada Seminar Nasional Pengajaran Matematika di 
Sekolah Menengah yang

dilaksanakan oleh Jurusan

Matematika FMIPA UM. Malang,

25 Maret 2000.

Suryanto, 1998. Problem Posing dalam

Pembelajaran

Matematika.

Makalah disajikan pada Seminar

Nasional:

Upaya-upaya

Meningkatkan Peran Pendidikan

dalam Menghadapi Era

Globalisasi. Program Pascasarjana

IKIP Malang, 4 April 1998.
Suryosubroto, B., 2009. Proses Belajar Mengajar di Sekolah. Jakarta; Rineka Cipta. Cet. Kedua (edisi revisi).

Sutiarso, S. 1999. Pengaruh Pembelajaran dengan Pendekatan Problem Posing Terhadap Hasil Belajar Aritmatika Siswa SMPN 18

Malang. Tesis Program Pascasarjana Universitas Negeri Malang: Tidak diterbitkan. 
